\title{
The Effect of the Change in the Balance Sheet Law in 2014-2018 on Management of Companies in Poland
}

\author{
Jolanta Chluska ${ }^{1}$ \\ ${ }^{1}$ Czestochowa University of Technology, Poland \\ Correspondence: Jolanta Chluska, Czestochowa University of Technology, Poland. E-mail: \\ jolanta.chluska@wz.pcz.pl
}

Received: October 24, 2019

Accepted: November 15, 2019

Online Published: December 22, 2019

doi:10.5430/rwe.v10n4p14

URL: https://doi.org/10.5430/rwe.v10n4p14

\begin{abstract}
Polish business entities operate based on accounting principles in accordance with the Accounting Act and the accounting policy established by the directors of the entities. Changes in the balance sheet law have a significant effect on the internal accounting principles applied in companies. In the last three years, Polish accounting regulations have been adapted to the solutions used in the European Union.

The aim of the paper is to analyse information aspects of accounting, including financial reporting in Poland in the decision-making processes of internal recipients, taking into account the changes in legal regulations.

The research method was the analysis of the literature and legal acts, and a practical example.

Changes in legislation influence the accounting policies defined by the managers of business entities. Companies can simplify their accounting principles including those concerning reporting. However, the simplifications should not adversely affect the economic decisions of the entity's manager and the recipients of the financial statements.

The lack of accurate financial data from the accounting system may adversely affect the decision-making of the unit's manager in management processes. As it results from the analysis of the literature of the subject and the accounting systems of small enterprises, financial information from accounting is necessary for effective business management. Therefore, managers apply simplifications in accounting quite carefully.
\end{abstract}

Keywords: Polish accounting law, accounting, management, accounting policy

\section{Introduction}

Business entities in Poland are obliged to keep accounts according to the Accounting Act and specific legal regulations. Based on the information obtained from the accounting systems, they prepare financial reports. The recipients of financial reports include a broad range of shareholder and other interested parties. They all expect that the information contained in the financial report is reliable, transparent and comparable.

If small entities simplify their accounting and reporting, there appears the research problem: how will this simplification affect management processes based on information obtained from accounting.

The provisions of the Accounting Act are used for the following entities with headquarters in the territory of the Republic of Poland:

1) commercial law companies (partnerships and corporations, including those in the process of formation) and civil law partnerships as well as other legal entities, excluding the State Treasury and the National Bank of Poland,

2) natural persons, civil law companies, registered partnerships of natural persons, limited liability partnerships, if their net incomes on sales of goods, products and financial operations for the previous financial year were an equivalent in Polish currency of at least 2,000,000 euro.

3) entities acting based on the regulations of the banking acts, regulations on securities exchange and investment funds, insurance and reinsurance activities, savings and credit unions, organization and operation of pension funds, regardless of the revenues,

4) municipalities, counties, voivodeships and their unions, including:

a) state, municipality, county and voivodeship budgetary entities, 
b) state, municipality, county and voivodeship budgetary enterprises,

c) state-owned special purpose funds. (Art. 2, Section 1 of the Accounting Act)

The act is composed of thirteen divisions which stipulate the basic principles of accountancy in the entities obliged to use them.

The aim of the paper is to analyse information aspects of accounting, including financial reporting in Poland in the decision-making processes of internal recipients, taking into account the changes in legal regulations The research methodology was the analysis of the literature and legal acts, and a practical example

The article consists of an introduction, three chapters and an ending containing final conclusions.

The first chapter discusses the accounting principles as a basis for obtaining information useful in making decisions in the management of the unit.

The second chapter describes changes in Polish accounting in the period 2014-2018. These changes were caused by the amendment of European Union directives.

The third chapter discusses the impact of simplifications in business accounting on the reliability of financial information.

A research hypothesis has been put forward that "the use of simplifications in accounting may negatively affect the accuracy of information in making decisions".

\section{Background: Accounting Principles as a Basis for Company Management}

The fundamental principles of accounting defined by the balance law include the following:

going concern principle,

consistency principle,

accrual basis principle,

matching principle,

prudence principle,

substance over form principle,

materiality principle,

accounting period principle.

Using the principle of going concern (Art. 5, Section 2 of the Accounting Act), it is adopted during valuation of assets and liabilities and determination of the financial result that the business entity should continue in the predictable future, their business activities with the scope that did not change substantially (they did not plan liquidation, did not start a bankruptcy proceedings or did not change a legal form).

Respecting the principle of consistency (Art 5, Section 1 of the Accounting Act) requires that the adopted principles for recording operations, valuation of assets and liabilities and determination of the financial result and preparation of reports should be the same over individual years. This will ensure comparability of information. The change in the principles can be made from the first day of the financial year as an exception, and for the important and justified causes.

According to the principle of accrual basis (Art 6, Section 1 of the Accounting Act), the accounting books in an entity and the financial result should take into consideration all the incomes generated in the entity and the related costs concerning a particular financial year, regardless of the due date for payment.

Maintaining the matching (Art. 6, Section 2 of the Accounting Act) of the revenues and costs and determination of real financial results necessitates including, in the assets and liabilities for a particular reporting period, of the costs for future periods, revenues for future periods, and the costs related to the given reporting period which will be incurred in the future.

Although referring to balance items, the prudence principle (Art 7, Sections 1 and 2 of the Accounting Act) has also a direct effect on the value of the resultant items It necessitates taking into consideration, in the financial result of the entity, regardless of the their level, a reduction in the asset's value in use, presentation of only indisputable operating revenues and extraordinary profits and recording all the operating expenses and extraordinary losses, reserves for the known risk, potential losses and effects of other events. 
The principle of substance over form (Art. 4, Section 2 of the Accounting Act) manifests in the obligation of recording economic events (including economic operations) in accounting books and financial reports according to their economic contents.

The principle of materiality (Art. 8, Section 1 of the Accounting Act) necessitates such organization of collecting the accounting data that it is possible to separate the data which are essential for determination of property and financial situation of the entity, its financial result and profitability.

The principle of accounting periods leads to the obligation of division of accounting activities into the accounting periods (months, years).

Application of the above specific principles ensures meeting the principle of true and fair view.

The conceptual assumptions of the financial reporting formulate the goal of the financial reporting in the following manner: "The aim of the overall financial reporting is to provide financial information about a reporting entity that is useful for potential investors, lenders and other creditors when making decisions on supplying the resources to the entity. These decisions concern purchase, sales and having capital and debt instruments and granting and payment of loans and other forms of crediting".

The usefulness of information in the financial statements determines their usefulness and faithful presentation. The usefulness of information is increased by its features such as comparability, verifiability, timeliness and intelligibility.

Polish accounting regulations do not formulate the purpose of financial statements, but are based on and consistent with International Accounting Standards in important respects.

The responsibility for accounting in a business entity is taken by the manager in the entity (single- or multi-person body, which is entitled to manage the entity: owner, liquidator, administrative receiver, administrator). These persons define and update, in a written form, the principles of accounting.

\section{Discussion: Directions of Changes in the Polish Balance Sheet Law in 2014-2018}

Based on Directive 2013/34/EU of the European Parliament and of the Council of 26 June 2013 on the annual financial statements, consolidated financial statements and related reports of certain types of entities, changes were introduced to the Polish accounting regulations in order to separate micro- and small entities. In the Polish Accounting Act, the amendments were made by the amending acts of 11 July 2014 and 23 July 2015 (Note 1).

The possibility of obtaining a status of a micro- or small enterprise depends on exceeding the thresholds for balance sheet total, revenues on the sale of goods and products and the number of employees. In the group of the smallest entities, the status of the micro-unit is determined by:

a) total assets of the balance sheet (PLN 1.5 million) of net revenues from the sale of goods and products (PLN 3 million), average annual employment rate converted into full-time equivalents (10 people) (Art. 3.1a, point 1,3,4 of the Accounting Act),

b) with respect to some entities, non-involvement in business activity (Art. 3.1a point 2 of the Accounting Act).

The status of a small entity is determined by the provisions of the Accounting Act, taking into account the following thresholds: total assets of the balance sheet (PLN 25.5 million), net revenues from the sale of goods and products (PLN 51 million), average annual level of employment converted into full-time equivalents (50 people) (Art. 3.1c of the UoR).

In order to adopt the status of a micro or small entity, the bodies approving financial statements (owners) must adopt resolutions on this matter.

Simplification of accounting and reporting of the micro unit was aimed to reduce labour intensity of accounting in enterprises. (Wysłocka, Biadacz, 2014) The simplifications are shown in Table 1. 
Table 1. Simplifications of accounting in micro entities

\begin{tabular}{|c|c|c|}
\hline $\begin{array}{l}\text { Accounting } \\
\text { area }\end{array}$ & Scope of simplification & $\begin{array}{l}\text { Legal } \\
\text { regulation }\end{array}$ \\
\hline \multirow{3}{*}{ 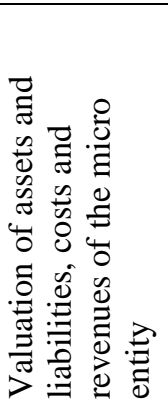 } & $\begin{array}{l}\text { The micro entity as referred to in Article } 3 \text {, section } 1 \mathrm{a} \text {, item } 2 \text { of the Polish } \\
\text { Accounting Act, is allowed not to use the principle of prudence in the valuation of } \\
\text { individual assets and liabilities. }\end{array}$ & $\begin{array}{l}\text { Article } \\
7.2 \mathrm{a}\end{array}$ \\
\hline & $\begin{array}{l}\text { The micro entity as referred to in Art. } 3 \text {, section 1a, item } 2 \text { of the Polish Accounting } \\
\text { Act, uses the difference between revenues and costs determined in the profit and } \\
\text { loss account to increase, after approval of the annual financial statements, the } \\
\text { revenues or costs, respectively, in the following financial year. The positive } \\
\text { difference may be allocated to the increase in share capital (fund). }\end{array}$ & $\begin{array}{l}\text { Article } 47 . \\
\text { 3a. }\end{array}$ \\
\hline & $\begin{array}{l}\text { A micro entity does not value the assets and liabilities at fair value and amortized } \\
\text { cost. }\end{array}$ & Article $28 \mathrm{a}$ \\
\hline \multirow{6}{*}{ 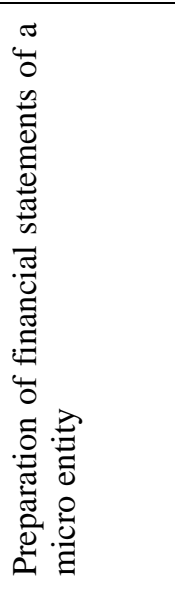 } & in information within the scope specified in & \\
\hline & & \\
\hline & $\begin{array}{l}\text { nit is allowed not to prepare additional information, provided that it } \\
\text { rmation supplementary to the balance sheet set out in Appendix } 4 \text { to } \\
\text { ag Act. }\end{array}$ & $\begin{array}{l}\text { Article } \\
48.3\end{array}$ \\
\hline & o entity is allowed not to prepare a statement of changes in equity (fund). & Art. 48a.3 \\
\hline & A micro entity is allowed not to present a cash-flow statement. & \\
\hline & $\begin{array}{l}\text { The micro entity as referred to in Art. } 3 \text {, section } 1 \mathrm{a} \text {, item } 1 \text { of the Accounting Act, } \\
\text { which is obliged to prepare a report on the entity's activity, are allowed not to } \\
\text { prepare this report, provided that in the additional information (information } \\
\text { supplementary to the balance sheet), it presents information on the acquisition of } \\
\text { own shares (stocks) specified in Appendix } 4 \text { to the Act. }\end{array}$ & $\begin{array}{l}\text { Article } \\
49.4\end{array}$ \\
\hline
\end{tabular}

Source: Author's own elaboration based on the Accounting Act.

Attachment 4 introduced to the Accounting Act allows for the preparation of the financial statements in a simplified version. (Note 2) In small entities, simplifications in reporting are presented in Table 2.

Table 2. Simplifications of accounting in small entities

\begin{tabular}{|c|c|c|}
\hline $\begin{array}{l}\text { Accounting } \\
\text { area }\end{array}$ & Scope of simplification & $\begin{array}{l}\text { Legal } \\
\text { regulation }\end{array}$ \\
\hline 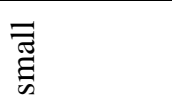 & $\begin{array}{l}\text { The balance sheet should contain information within the scope specified in } \\
\text { Appendix } 5 \text { of the Accounting Act. }\end{array}$ & $\begin{array}{l}\text { Article } \\
46.5 .5\end{array}$ \\
\hline \multirow{2}{*}{ 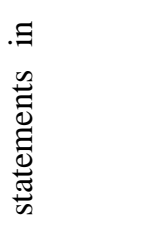 } & $\begin{array}{l}\text { The profit and loss account for small entities preparing a simplified profit and loss } \\
\text { account should contain information within the scope specified in Appendix } 5 \text { to the } \\
\text { Accounting Act, in a calculation or comparative variant, depending on the choice } \\
\text { made by the entity's manager. }\end{array}$ & $\begin{array}{l}\text { Article } \\
47.4 .5,\end{array}$ \\
\hline & $\begin{array}{l}\text { The scope of additional information for small units preparing simplified additional } \\
\text { information is specified in Appendix No. } 5 \text { to the Act. A small entity, which does }\end{array}$ & $\begin{array}{l}\text { Article } \\
48.4\end{array}$ \\
\hline \multirow{3}{*}{ 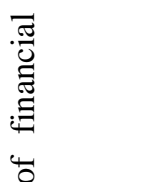 } & $\begin{array}{l}\text { not prepare a simplified additional information, prepares additional information in } \\
\text { the scope not smaller than specified in Appendix } 5 \text { to the Accounting Act. }\end{array}$ & \\
\hline & A small entity is allowed not to prepare a statement of changes in equity (fund). & Art. 48a.4 \\
\hline & A small entity is allowed not to present a cash-flow statement. & $\begin{array}{l}\text { Article } \\
48 b .5\end{array}$ \\
\hline \multirow{2}{*}{ 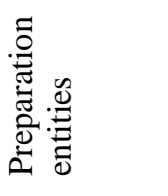 } & $\begin{array}{l}\text { A small entity that is obliged to prepare reports on activities is allowed not to } \\
\text { prepare the report provided that the additional information contains information } \\
\text { about acquisition of own shares. }\end{array}$ & $\begin{array}{l}\text { Article } \\
49.5\end{array}$ \\
\hline & $\begin{array}{l}\text { A small entity is allowed not to present non-financial indicators in the report and } \\
\text { environmental and employment information in the report on activities. }\end{array}$ & $\begin{array}{l}\text { Article } \\
49.6\end{array}$ \\
\hline
\end{tabular}

Source: Author's own elaboration based on the Accounting Act. 
In terms of keeping accounting books and organisation of accounting, the opportunities for simplification of small entities are relatively small (Gos, Hońko, 2008).

Entities that do not have the status of a micro or small entity apply Appendix 1 to the Accounting Act, which provides for the preparation of a financial statement consisting of:

a) balance sheet,

b) profit and loss account,

c) additional information (introduction to the financial statement and additional information and explanations),

d) cash flow account,

e) statement of changes in equity.

The last two components of the financial statement are prepared by entities required to be examined by statutory auditors.

A balance sheet in a business entity is a presentation of property components (assets) and sources of finance (liabilities). The assets are presented according to the balance sheet evaluation defined by the accounting policy adopted by the entity and described in the documentation of the principles of accountancy adopted.

The balance sheet demonstrates the levels of assets and liabilities for the dates that close current and previous financial years. If the balance is prepared for the balance sheet date other than a date that closes current financial year, the balance has to present the assets and liabilities for this day and the day that closes the year directly before the balance sheet date.

Profit and loss account is prepared by the entities in comparative or calculation variants. The choice of the variant of profit and loss account depends on the choice of the entity and is determined with the cost recording method. If the business entity keeps cost records in a simplified variant using the cost accounts, they are allowed to prepare a comparative variant for the profit and cost account. If the simplified variant of cost records includes the accounts according to the costs centres, the entity is allowed to prepare the calculation variant of the profit and loss account. In the case of full cost records, i.e. both in the accounts of costs according to nature and to types of activities, the entity is allowed to prepare both comparative and calculation variant of profit and loss account. However, the entity chooses one of them and prepares the statement of expenses and revenues in a comparable manner in consecutive reporting periods. Comparative and calculation variants of the profit and loss account differ in the method of determination of the sales figures. In the calculation variant, the revenues on sales of products, goods and materials are deducted the prime cost of sales (costs of goods sold, costs of management and sales) and the value of goods and materials sold. In the comparative version, the sales figures are obtained as a difference between net revenues on sales of products, goods and materials and the compared (change in the products status, cost of production for internal needs in the entity) and the costs of operational activity according to types increased by the value of goods and materials sold. The sales figures are added other operating costs and deducted other operating costs, thus obtaining the result on operational activities. This result is corrected by other groups of revenues and costs i.e. financial revenues and costs. The gross financial result reduces the income tax in the entity. The final financial result is the net result (profit/loss).

The additional information is supplementary with respect to the items in the balance, profit and loss account, comparison of changes in equity and the cash flow account for the reporting periods included in financial reports. This information concerns the two thematically separated components i.e.:

a) introduction to the financial report,

b) additional information and explanations.

Comparison of changes in equity contains information about changes in individual components of equity for current and previous financial year. Preparation of them is obligatory in the business entities which are obliged to auditing of financial reports. The entities that do not have this obligation present information about changes in equity in the additional information section (additional information and explanation). Comparison of changes in equity is prepared by the entities with varied structure and scope of capitals. Therefore, the share capital is represented by equity (founding) capital, whereas in the entry concerning the supplementary capital, entities present the capitals which come from self-financing (division of profits).

Cash flow is prepared by business entities obliged to audit their financial reports according to the Art. 64 of the Accounting Act. The cash flow account takes into consideration the revenues and expenditures on operating, investment and financial activities of the entity. The cash flow account presents transactions included into the statement on the cash basis. 
The subject of the information values of financial statements of small entities is widely described in the literature (Maćkowiak 2018, Osikowicz 2011, Juźwicka 2013, Zieliński 2008, Żukowska 2016, Blackburn et al. 2013, Dobbs, Hamilton 2007, Lobontiu 2002). Based on the financial data from the accounting system, various indicators are calculated, eg profitability ratios, liquidity ratios. Incorrect financial data causes the indicators to be not true. (Jerzemowska 2004) Analyzes and scientific discussions point to the lack of comparability of financial indicators of small and large enterprises, not only because of the size of their resources, but also because of the quality of financial data. (Dudycz et al., 2005)

In 2015 the author has conducted research in 37 entities applying the provisions of the Accounting Act and asked the question: "Are you going to apply simplified accounting principles for micro / small units in 2016?" Out of the surveyed units, only 3 declared application simplifications for micro entities and 8 entities - simplifications for small entities in 2016. The others did not plan any simplifications.

The most frequently used accounting simplifications were:

a) resignation from determining deferred income tax,

b) omitting the purchase costs in the balance-sheet valuation of inventories (valuation according to purchase costs).

As research shows, enterprises decide to use simplifications, but introduce them slowly and in a rational way. (Chluska 2016)

Surveys and interviews were also conducted by O. Martyniuk-Kwiatkowska in 2009 on a sample of 100 small enterprises from the Pomeranian Voivodeship. She observed that small enterprises mostly use internal financial information. They are interested in information such as:

a) costs in various cross-sections,

b) sources of income,

c) payment capability,

d) the efficiency of inventory management,

e) production efficiency.

She also distinguishes between distortions of financial statements for those which increase the value of financial statement items and those which reduce distortions. (Martyniuk-Kwiatkowska 2009).

\section{Results: Decision-Making Aspects of Balance Sheet Law}

The chief executive of the entity, who determines the principles for accounting policy, has an essential influence on the value of assets and liabilities, costs and revenues in the financial report. Therefore, they control the view of the enterprise and have an influence on the economic decision of external recipients of the accountancy. There are two-way relationships in the decision-making processes of business entities:

a) executives influence on the value of assets and liabilities, expenses and revenues in the financial report,

b) based on these values, they make current and periodical decisions.

In some cases, a conflict might occur in these relations. For instance, a chief executive makes a decision on creation of the write-down that reduces the value of receivables in the balance sheet and affects a reduction in the current assets. Liquidity ratios are deteriorated. Based on the calculated liquidity ratios, executives make periodical decisions on acquisition of new sources of finance. However, the opposite situation might also occur. Excessively liberal policy in terms of write-downs does not change the financial analysis ratios and can be the cause of erroneous decisions based on improper value of current assets. Similar consequences can be observed in profitability and solvency.

With the use of simplifications, accounting books and reporting may fail to provide complete information on the assets and liabilities of the entity. Any simplification in terms of assets and liabilities affects the financial result. Examples of simplification effects are presented in Table 3. 
Table 3. Possible effects of simplifications in the accounting of small entities

\begin{tabular}{|c|c|}
\hline Simplification & Negative effects of simplifications \\
\hline $\begin{array}{l}\text { qualification of leasing agreements according to } \\
\text { the rules contained in tax regulations (Art. } 3.6 \\
\text { of the Accounting Act) }\end{array}$ & $\begin{array}{l}\text { - lack of information on fixed assets used in business } \\
\text { activity, } \\
\text { - no depreciation in operating costs, } \\
\text { - underestimated production costs, }\end{array}$ \\
\hline $\begin{array}{l}\text { withdrawal from the use of the provisions of the } \\
\text { Ordinance of the Minister of Finance of } 12 \\
\text { December } 2001 \text { (Art. 28b.1 of the Accounting } \\
\text { Act), }\end{array}$ & $\begin{array}{l}\text { - no information on hedge accounting, } \\
\text { - lack of information on the amortized cost of financial } \\
\text { instruments, } \\
\text { - imprecise classification of financial assets, }\end{array}$ \\
\hline $\begin{array}{l}\text { Withdrawal from the determination of deferred } \\
\text { income tax assets and provisions (Art. } 37.10 \text { of } \\
\text { the Accounting Act) }\end{array}$ & $\begin{array}{l}\text { - net financial result (overstated or understated), } \\
\text { - inaccurate basis for the calculation of financial ratios, }\end{array}$ \\
\hline $\begin{array}{l}\text { Opportunity for non-adjustment of the } \\
\text { production cost by the costs of unused } \\
\text { production capacity (Art. 28.4a of the } \\
\text { Accounting Act) }\end{array}$ & $\begin{array}{l}\text { - misrepresented manufacturing cost, } \\
\text { - inaccurate analyses of product profitability. }\end{array}$ \\
\hline
\end{tabular}

Source: Author's own elaboration based on the Accounting Act.

The effect of simplifications on financial information about the company is presented in the example below.

\section{Example}

Company X from the textile sector applied simplification of tax reporting of fixed assets used in operations under lease agreements. When the company could no longer apply this simplification because it exceeded the thresholds for small entities, it was obliged to enter fixed assets from leasing contracts into its accounting books and financial statements. Consequently, the following changes occurred:

a) the balance sheet total increased by PLN 1,443 thousand (5\% of the balance sheet total),

b) amortization costs increased by 146 thousand zlotys.

c) Financial costs increased by 52 thousand zlotys.

In total, the costs entered into the books accounted for $21 \%$ of the net financial result.

As shown by the example, the financial data characterising the company were inaccurate. Financial ratios calculated before and used in the entity's decision-making processes were also incorrect.

The executives in the enterprise use information from the accounting systems for management of the entity in short and long periods. According to the balance sheet law in Poland, accountancy is a responsibility of the entity's chief executive and, in selected areas, a person who was entitled to keep the accounting books. The competencies of the chief executive include in particular:

a) preparation and updating documentation for the adopted accounting principles,

b) separation and characterization of all the essential areas of evaluation in the accounting policy,

c) responsibility for stocktaking in the form of physical inventory,

d) determination of the principles of evaluation of assets and liabilities, expenses and revenues in the area which leaves it up to the entity to choose the principles not regulated by legal acts,

e) ensuring that the financial report and the operating statement meet the requirements of the Accounting Act and other legal regulations,

f) ensuring that the annual report is prepared not later than on three months from the balance sheet date and present it in the appropriate bodies,

g) concluding the financial report,

h) concluding, with the entity entitled to audit financial reports, a contract of audit or review of the financial report. 


\section{Conclusion}

Transformation of the balance sheet law in Poland brought Polish accountancy closer to the international standards. The balance law in Poland does not regulate many essential principles of accountancy in business entities, leaving the details up to the executives in the entities within the adopted internal accountancy policies. The financial report should provide recipients with reliable and credible economic information. Making the decisions based on the reports has to, however, take into consideration the risk of subjectivity of the opinion and evaluation of economic events recorded in the systems of accountancy i.e. accounting policy.

If managers make decisions on simplification of accounting and reporting rules, they have to reckon with:

a) inaccurate balance sheet total of assets and liabilities,

b) overstated or understated financial result,

c) overstated or understated unit cost of production.

The lack of accurate financial data from the accounting system may adversely affect the decision-making of the unit's manager in management processes. The conducted analyzes allow to state that the research hypothesis has been verified positively.

\section{References}

Blackburn, R. A., Hart, M., \& Wainwright, T. (2013). Small business performance: business, strategy and owner-manager characteristics. Journal of Small Business and Enterprise Development, 20(1), 8-27.

Chluska J. (2016). Uproszczenia rachunkowości jednostek mikro i matych - szanse i zagrożenia. Studia Ekonomiczne, Zeszyty Naukowe Uniwersytetu Ekonomicznego w Katowicach nr 268, Katowice, p. 70.

Dobbs, M., \& Hamilton, R. (2007). Small business growth: recent evidence and new directions. International Journal of Entrepreneurial Behaviour \& Research, 12(5), 296-322.

Dudycz, T., Hamrol, M., Skoczylas, W., \& Niemiec, A. (2005). Finansowe wskaźniki sektorowe - pomoc przy analizie finansowej i ocenie zdolności przedsiębiorstwa do kontynuacji działalności. Rachunkowość nr 3, p. 1 46.

Dyrektywa Parlamentu Europejskiego i Rady 2013/34/UE z dnia 26 czerwca 2013 r. w sprawie rocznych sprawozdań finansowych, skonsolidowanych sprawozdań finansowych i powiązanych sprawozdań niektórych rodzajów jednostek, zmieniająca dyrektywę Parlamentu Europejskiego i Rady 2006/43/WE oraz uchylająca dyrektywy Rady 78/660/EWG i 83/349/EWG, Dz. Urz. L 182/19 z 29.6.2013.

Gos, W., Hońko, S., \& Rublewski, M. (2008). Granice uproszczeń rachunkowości małych i średnich przedsiębiorstw. Zeszyty Teoretyczne Rachunkowości, 47(103), Warszawa, p. 57.

Jerzemowska, M., red. (2004). Analiza ekonomiczna w przedsiębiorstwie. PWE, Warszawa, p. 28.

Juźwicka, A. (2013). Organizacja rachunkowości w opinii menedżerów małych przedsiębiorstw. Zeszyty Naukowe Politechniki Łódzkiej Nr 1145, Organizacja i Zarządzanie, vol. 50, p. 199 - 208.

Lobontiu, G. (2002). Strategies and Strategic Management in Small Businesses. MPP Working Paper No. 15/2002, p. $1-31$.

Maćkowiak, E. (2018). Zmiany $w$ zakresie prezentacji kosztów $w$ sprawozdaniu finansowym mikro, małych $i$ średnich podmiotów a zarządzanie wartościa przedsiębiorstwa. Zeszyty Naukowe Politechniki Częstochowskiej, Zarządzanie nr 30, s. 190-205.

Martyniuk-Kwiatkowska, O. (2009). Wykorzystanie danych sprawozdawczości finansowej w ocenie działalności matych przedsiębiorstw. Zeszyty Teoretyczne Rachunkowości, tom 48 (104), Warszawa, p. 113-117.

Nowak, E. (2014). Ujawnianie informacji w sprawozdaniach finansowych a wielkość jednostki gospodarczej $w$ świetle nowej dyrektywy Parlamentu Europejskiego i Rady. Zeszyty Naukowe Uniwersytetu Szczecińskiego nr 802, Finanse, Rynki Finansowe, Ubezpieczenia”, nr 65, Wydawnictwo Naukowe Uniwersytetu Szczecińskiego, Szczecin, p. 310.

Osikowicz, M. (2011). Rachunkowość małych firm w kontekście problemu dotacji unijnych. Zeszyty Naukowe Uniwersytetu Ekonomicznego w Krakowie nr 861, p. 135 - 146.

Remlein, M. (2010). Funkcja informacyjna rachunkowości a wycena wedtug wartości godziwej. In B. Micherda (red.), Perspektywy rozwoju rachunkowości, analizy i rewizji finansowej w teorii i praktyce. Tom 2. Studia i 
Prace Uniwersytetu Ekonomicznego w Krakowie nr 14, Wydawnictwo Uniwersytetu Ekonomicznego w Krakowie, Kraków, p. 162, 163.

Rówińska, M. (2014). Zakres sprawozdania finansowego matych i średnich jednostek gospodarczych, Zeszyty Naukowe Uniwersytetu Szczecińskiego nr 827, Finanse, Rynki Finansowe, Ubezpieczenia, nr 69. Wydawnictwo Naukowe Uniwersytetu Szczecińskiego, Szczecin, p. 223.

The Act as of 29 September 1994 on accounting, Journal of Laws of 2018, item 395 with further amendments.

The Act of 11 July 2014 amending the Accounting Act, Journal of Laws 2014, item 1100.

The Act of 23 July 2015 amending the Accounting Act and certain other acts. Journal of Laws 2015, Pos. 1333.

Wysłocka, E., \& Biadacz, R. (2014). Ocena zmian w uproszczonej sprawozdawczości mikropodmiotów. Zeszyty Naukowe Uniwersytetu Szczecińskiego "Finanse, Rynki Finansowe, Ubezpieczenia" nr 71 (832), Wydawnictwo Naukowe Uniwersytetu Szczecińskiego, Szczecin, p. 181, 182.

Założenia koncepcyjne sprawozdawczości finansowej, MSSF 2011, SKwP, Warszawa 2011.

Zieliński, J. (2008). Outsourcing doradztwa podatkowego i rachunkowości w małej firmie. Wolter Kluwers Business, Warszawa, pp. 160-162.

Żukowska, H. (2016). Sprawozdawczość finansowa przedsiębiorstw niefinansowych według znowelizowanej do 2015 roku ustawy o rachunkowości. Roczniki Ekonomii i Zarządzania, 8(44), nr 1, pp. 7-53.

\section{Notes}

Note 1. The Act of 11 July 2014 amending the Accounting Act, Journal of Laws 2014, item 1100, Act of 23 July 2015 amending the Accounting Act and certain other acts, Journal of Laws 2015, Pos. 1333.

Note 2. Micro entities do not value the assets and liabilities at fair value and amortized cost. With regards to fair value estimation in the context of the informational function of accounting, interesting considerations can be found in the study by M. Remlein, cf. Remlein, 2010. 